\title{
Effects of alloy elements on mechanical properties of low alloy wear resistant steel
}

\author{
Wenfeng Zhang ${ }^{1,2}$, Zhong Liu ${ }^{1 *}$, Tianming Li $^{1}$, Xiaogang Liu ${ }^{2}$, Wei Xiong ${ }^{1}$ \\ ${ }^{1}$ School of Mechanical Engineering, Gulin University of Aerospace Technology, Guilin 541004 China \\ ${ }^{2}$ Guangxi Colleges and Universities Key Laboratory of Robot \& Welding, Guilin University of Aerospace Technology, Guilin 541004, \\ China
}

\begin{abstract}
This work is mainly concerning with effects of Carbon, Nickel and vanadium on mechanical properties of low alloy wear resistant steel. the results showed that The experimental steels yielded their best comprehensive properties at $940{ }^{\circ} \mathrm{C}$ of quenching and at $200{ }^{\circ} \mathrm{C}$ of tempering for $0.33 \mathrm{wt} \% \mathrm{C}$ steel, at 940 ${ }^{\circ} \mathrm{C}$ of quenching and at $220^{\circ} \mathrm{C}$ of tempering for $0.38 \mathrm{wt} \% \mathrm{C}$ steel, and at $920^{\circ} \mathrm{C}$ of quenching and at $230{ }^{\circ} \mathrm{C}$ of tempering for $0.4 \mathrm{wt} \% \mathrm{C}$ steel, respectively. $3 \% \mathrm{Ni}$ steel yielded the best property at $900{ }^{\circ} \mathrm{C}$ quenching and $200{ }^{\circ} \mathrm{C}$ tempering, while $5 \% \mathrm{Ni}$ steel was $920{ }^{\circ} \mathrm{C}$ quenching and $200{ }^{\circ} \mathrm{C}$ tempering. The best property yielded at $940{ }^{\circ} \mathrm{C}$ quenching and $200^{\circ} \mathrm{C}$ tempering for the Vanadium addition steel.
\end{abstract}

\section{Introduction}

Wear is the material lose and/or transfer phenomena on two contacted object surfaces that have comparative motion $^{[1]}$. Generally, wear can be divided into two categories: one is wear that relates to mechanical properties of materials, the other one is dominated by chemical and thermal activation processes ${ }^{[2]}$. Special steels that serve in wear conditions are wear resistant steels. Early types of wear resistant steel commonly contain high content of alloy elements ${ }^{[1]}$. Thus, developing low alloy wear resistant steel provides an important approach to reduce challenges raised by huge requirements, resource self-sufficiency and environment protection.

Carbon has a critical effects on the microstructure and properties of low alloy wear resistant steels ${ }^{[3]}$. the addition of Carbon would increase hardness and reduce toughness. Carbon would accelarate austenite forming 30 times as large as $\mathrm{Nickel}^{[4]}$. When Carbon content was higher than $1 \%$, acicular plate martensite became the dominant morphology. Lath structure was refined with increasing Carbon content. When Carbon content is lower than $0.27 \mathrm{wt} \%$, lath martensite and retained austenite or lath martensite, bainite and retained martensite can be acquired when quenched into water, resulting in nice plasticity and toughness ${ }^{[5]}$. However, their hardness was lower than $45 \mathrm{HRC}$, leading to poor wear resistance. If Carbon content was larger than 0.33 $\mathrm{wt} \%$, hardness enhancement was obvious, but toughness was steeply reduced. Water quenching cracks emerge, when Carbon content exceeded $0.38 \mathrm{wt} \%$.

Nickel was an element that stablized austenite. Nickel, in mutual solution with iron, existed in both $\alpha$ and $\gamma$ phase of steels, and strengthened them. It refined grains in $\alpha$ phase, so that nickel improved low temperature properties of steel, espercially toughness. Due to reducing critical transition temperature and element disfusion speed in steels, nickel enhanced their hardability ${ }^{[6]}$. When used in high content, nickel could remarkably improve some physical properties of steels. Its negative effects on toughness, plasticity and other properties were lower than that of other alloy elements, when it was used to enhance steels' strength.

Vanadium is an element that participated in carbides and nitrides forming. Vanadium increases solving time of carbides in austenite and homogenizing time of austenite composites. Solubility of vanadium in austenite is small and it formed dispersion particles to prevent the growth of austenite ${ }^{[7]}$. Thus, it refines grains and improves steel toughness.

The major effect of boron in steel was to improve its hardenability. Boron's effects on hardenability relates to its content, Carbon content and austenize temperature. The optimal boron content was claimed to be about $0.0010 \mathrm{wt} \%$. Its effect commonly decreased with increasing Carbon content ${ }^{[8]}$. Under optimal austenize temperature, hardenability introduced by boron reaches its maximum.

This work focued on effects of $\mathrm{C}, \mathrm{Ni}$ and $\mathrm{V}$ on microstructure and properties of low alloy wear resistant steels. The hardness and impact toughness of low alloy wear resistance steels with different alloy composition were tested.

\section{Experimental}

Table 1 gives the actual chemical composition of tested steels. After casting, steel ingots were cut into slabs with a grinding wheel cutter. Then these slabs were

*Corresponding author's e-mail: zwf@guat.edu.cn 
partitioned into blocks with a Type DK77 numerical controlled wire-electrode cutting machine tool. These specimens were heat treated according to following procedures. First, they were heated at $1020^{\circ} \mathrm{C}$ for $0.5 \mathrm{~h}$, air cooling to room temperature, or heated at $1160^{\circ} \mathrm{C}$ for $24 \mathrm{~h}$, furnace cooling to room temperature. Second, they were austenized at $860-980^{\circ} \mathrm{C}$ for $0.5 \mathrm{~h}$, water quenching. Third, tempering was carried out at $150^{\circ} \mathrm{C}-600^{\circ} \mathrm{C}$ for $2 \mathrm{~h}$. Austenization is performed in Type SSJ-IIA high temperature chamber electric furnace and low temperature tempering is carried out in Type SX2-8-10 chamber electric furnace.

Table 1 Chemical composition of investigated steels, mass \%

\begin{tabular}{ccccccccc}
\hline LAWRS steel & $\mathrm{C}$ & $\mathrm{Si}$ & $\mathrm{Mn}$ & $\mathrm{Cr}$ & $\mathrm{Mo}$ & $\mathrm{Al}$ & $\mathrm{Ni}$ & others \\
\hline 3C0Ni0V & 0.29 & 1.82 & 0.94 & 1.96 & 0.30 & 0.03 & - & - \\
3C03Ni0V & 0.30 & 1.85 & 1.00 & 1.94 & 0.35 & 0.33 & 0.31 & - \\
3C0Ni02V & 0.30 & 1.79 & 0.97 & 1.96 & 0.32 & 0.05 & - & $\mathrm{V} 0.19$ \\
$4 \mathrm{C} 0 \mathrm{Ni0V}$ & 0.41 & 1.83 & 0.98 & 1.95 & 0.31 & 0.04 & - & - \\
$2 \mathrm{C} 0 \mathrm{Ni0V}$ & 0.25 & 0.90 & 1.00 & 1.90 & 0.53 & 0.03 & - & - \\
$2 \mathrm{C} 3 \mathrm{Ni0V}$ & 0.20 & 0.92 & 0.99 & 1.88 & 0.55 & 0.02 & 2.97 & - \\
$2 \mathrm{C} 5 \mathrm{Ni0V}$ & 0.22 & 0.95 & 1.05 & 1.99 & 0.49 & 0.04 & 4.68 & $0.21 \mathrm{~V}$ \\
$2 \mathrm{C} 3 \mathrm{Ni02V}$ & 0.18 & 1.02 & 0.98 & 2.10 & 0.46 & 0.01 & 2.97 & $<0.001 \mathrm{~B}$ \\
$2 \mathrm{C} 5 \mathrm{Ni0V}$ & 0.21 & 0.94 & 1.06 & 2.00 & 0.50 & 0.02 & 4.68 & $<$ \\
\hline
\end{tabular}

Tested mechanical properties included impact toughness and hardness. The impact samples were standard Type $\mathrm{V}$ impact sample with size of $10 \mathrm{~mm} \times 10 \mathrm{~mm} \times 55 \mathrm{~mm}$. The impact tests were implemented with Type JB-30B pendulum impact testing machines following China standard GB/T229-1994. The absorbed energy of fracture was determined by Charpy impact test. Rockwell hardness was tested with Type HR150A hardness tester according to China standard GB/T230-1991. Hardness tests were generally carried out in impact specimens before impact tests. Values of hardness tests were the average of three valid data.

\section{Results and Discussion}

\subsection{Effects of Carbon on mechanical properties}

The hardness and impact toughness of samples with different Carbon content quenching at different temperature then tempering at $230^{\circ} \mathrm{C}$ was given in Figure 1. Figure 1(a) illustrated effects of Carbon content on

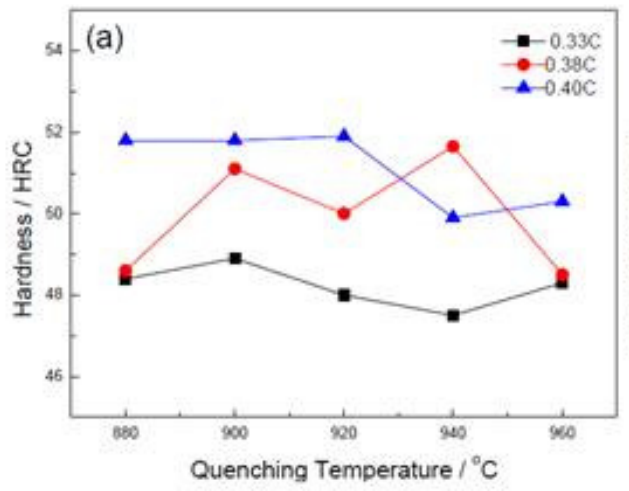

hardness. It could be seen that hardness increased apparently with raising Carbon content. For samples containing $0.33 \mathrm{wt} \%$ Carbon, hardness barely changed when quenching temperature increased. in the range of $900-940^{\circ} \mathrm{C}$, hardness of sample containing $0.38 \mathrm{wt} \%$ Carbon reached its maximum value. If it was quenched under $920^{\circ} \mathrm{C}$, hardness of $0.40 \mathrm{wt} \%$ Carbon samples only changed slightly. While quenching temperature was above $940^{\circ} \mathrm{C}$, its hardness reduced obviously. Figure 1(b) illustrated effects of Carbon content on cryogenic impact toughness of samples quenching at different temperature. In general, impact toughness reduced obviously with increasing Carbon content. Generally, impact toughness of samples with same Carbon content enhanced with higher quenching temperature. To be specific, for $0.33 \mathrm{wt} \%$ Carbon samples, their impact toughness increased with quenching temperature, and reached its maximum when quenching at $940^{\circ} \mathrm{C}$. For samples containing $0.38 \mathrm{wt} \%$ Carbon, the best comprehensive property was achieved when quenching at $940^{\circ} \mathrm{C}$. For samples containing $0.4 \mathrm{wt} \%$ Carbon, it was at $920^{\circ} \mathrm{C}$.

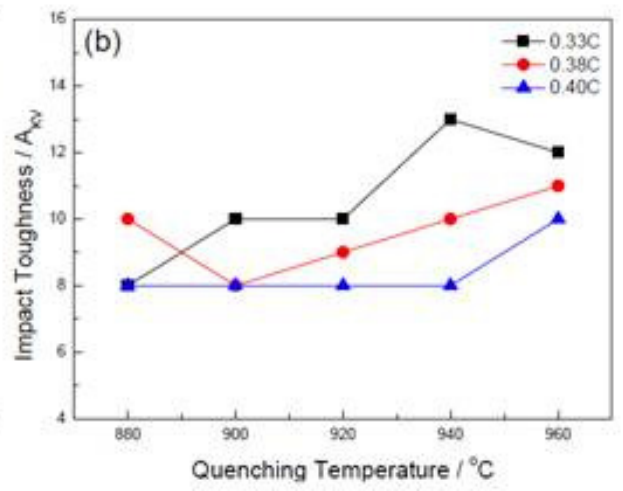

Figure 1. Mechanical properties of samples containing different Carbon after quenching at $230{ }^{\circ} \mathrm{C}$

Figure 2 showed hardness and cryogenic impact toughness for samples owning different Carbon content quenching at $940^{\circ} \mathrm{C}$, then tempering at different temperature. Figure 2(a) illustrated hardness vs tempering temperature curves. For samples containing
$0.33 \mathrm{wt} \%$ Carbon, hardness decreases drastically with increasing tempering temperature; for $0.38 \mathrm{wt} \%$ Carbon samples, the hardness reached its maximum at $200^{\circ} \mathrm{C}$ tempering temperature, but decreased drastically when tempering at $220^{\circ} \mathrm{C}$. For $0.40 \mathrm{wt} \%$ Carbon samples, 
hardness had peaks at $240^{\circ} \mathrm{C}$ and $300^{\circ} \mathrm{C}$ tempering temperature. When tempering at $240^{\circ} \mathrm{C}$, there was needle-like $\varepsilon$-carbide in lath; while at $300^{\circ} \mathrm{C}$, it transformed into tiny elliptical $\mathrm{Fe}_{3} \mathrm{C}$ particles, enhancing matrix. Figure 2(b) showed the variation of cryogenic impact toughness. As tempering temperature increased,

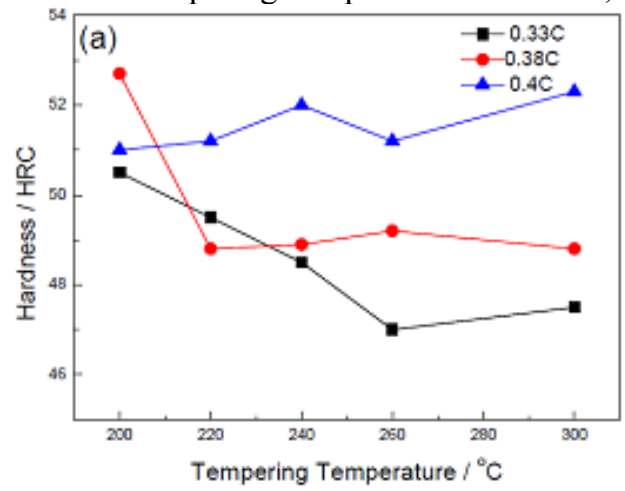

impact toughness first increased then decreased. For 0.33 wt $\%$ Carbon samples, tempering at $200^{\circ} \mathrm{C}$ yielded best mechanical properties. For $0.38 \mathrm{wt} \%$ Carbon samples, it was at $220^{\circ} \mathrm{C}$. and for $0.4 \mathrm{wt} \%$ Carbon content, it was at $240^{\circ} \mathrm{C}$.

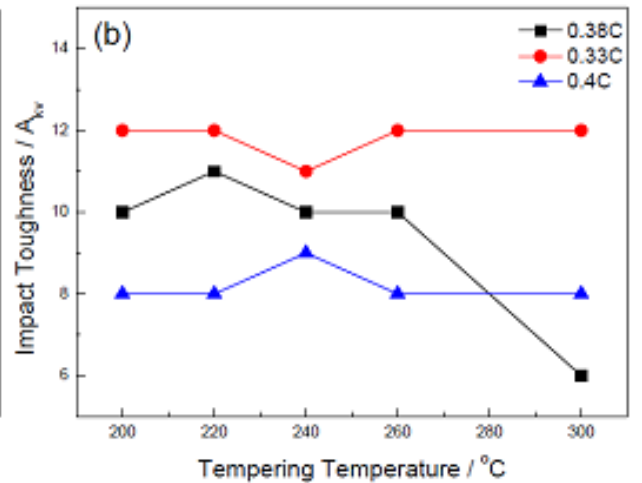

Figure 2. Mechanical properties of samples containing different amount of Carbon tempered at different temperatures.

\subsection{Effects of Nickel on mechanical properties}

Figure 3 showed mechanical properties of sample with different nickel content after quenching at different temperature then tempering at $230^{\circ} \mathrm{C}$. Figure $3(\mathrm{a})$ showed hardness-quenching temperature curve. Hardness of $0 \mathrm{Ni}$ steel first increases with higher quenching temperature, then decreased, and reached its highest value when quenching at $900^{\circ} \mathrm{C}$. However, its hardness was lower than the other two steels, due to its lower Carbon content $(0.3 \mathrm{wt} \%$ vs $0.33 \mathrm{wt} \%)$. $3 \mathrm{Ni}$ steel had the same Carbon content as $5 \mathrm{Ni}$ steel, while the hardness of $5 \mathrm{Ni}$ steel was lower than that of $3 \mathrm{Ni}$ steel. When quenching at $900^{\circ} \mathrm{C}$,

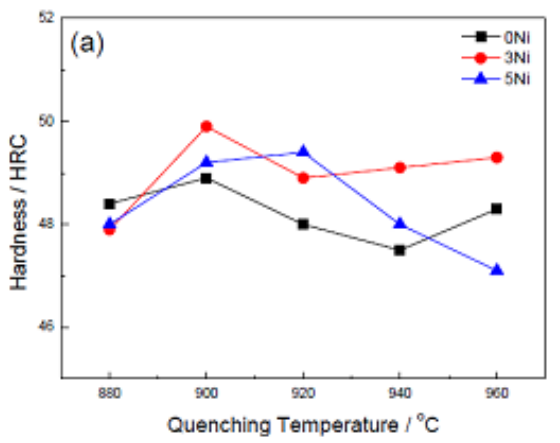

$3 \mathrm{Ni}$ steel had the greatest hardness. For $5 \mathrm{Ni}$ steel, the hardness of $900^{\circ} \mathrm{C}$ quenching and $920^{\circ} \mathrm{C}$ quenching were almost the same. Figure 3(b) was the cryogenic impact toughness vs quenching temperature curves. Although Carbon content in $0 \mathrm{Ni}$ steel was low, its impact toughness was lower than that of $0.33 \mathrm{wt} \% \mathrm{C}$ steel. The reason was due to nickel element in $0.33 \mathrm{wt} \% \mathrm{C}$ steel, which acts as an austenite stable element, increasing retained austenite in quenching microstructure, resulting a higher toughness. As quenching temperature increased, impact toughness generally enhanced. For $0 \mathrm{Ni}$ steel, the best quenching temperature is $960^{\circ} \mathrm{C}$; for $3 \mathrm{Ni}$ steel, $900^{\circ} \mathrm{C}$; for $5 \mathrm{Ni}$ steel, $920^{\circ} \mathrm{C}$.

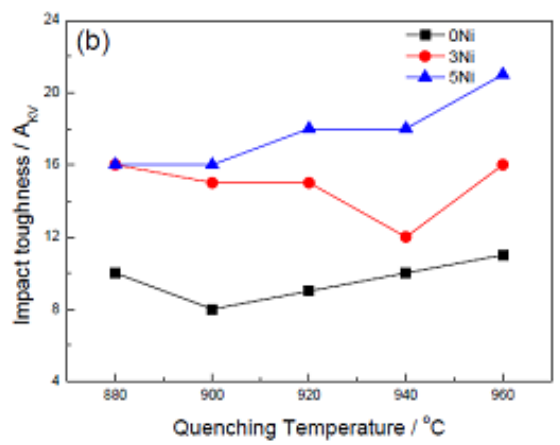

Figure 3. Effect of quenching temperature on mechanical properties of sample with different nickel content

Figure 4 illustrated mechanical properties of samples with different nickel content at different tempering temperature. Figure 4(a) illustrated hardness vs tempering temperature curve. As tempering temperature increased, hardness of $0 \mathrm{Ni}$ steel drastically decreased and reached its minimum value at $260^{\circ} \mathrm{C}$. While, the lowest hardness value of $3 \mathrm{Ni}$ steel and $5 \mathrm{Ni}$ steel emerged at $220^{\circ} \mathrm{C}$ tempering. Then as temperature elevated, hardness increased and achieved their maximum. Because when tempering at $200^{\circ} \mathrm{C}$, solution strengthen was the major strengthen mechanism of steel, and Carbon, in the form of $\mathrm{Fe} 3 \mathrm{C}$, existed in matrix during $200^{\circ} \mathrm{C}$ tempering. Under this temperature, retained austenite had decomposed into $\mathrm{Fe}_{3} \mathrm{C}$ and ferrite. The carbide is particle and scatters in matrix. If tempering temperature was above $220^{\circ} \mathrm{C}, \mathrm{Fe} 3 \mathrm{C}$ began to grow and aggregated to form needle-like shape, thus impact toughness was reduced. However, Fe3C strengthened the matrix as hard points, so the hardness increased. When tempering above $260^{\circ} \mathrm{C}$, ferrite started to recover, and changed from needle-like shape to polygon. Solved Carbon in matrix reached its lowest value, leading to another arise of impact toughness and reduction of hardness. Both $3 \mathrm{Ni}$ steel and $5 \mathrm{Ni}$ steel had the best properties when tempering at $200^{\circ} \mathrm{C}$ 

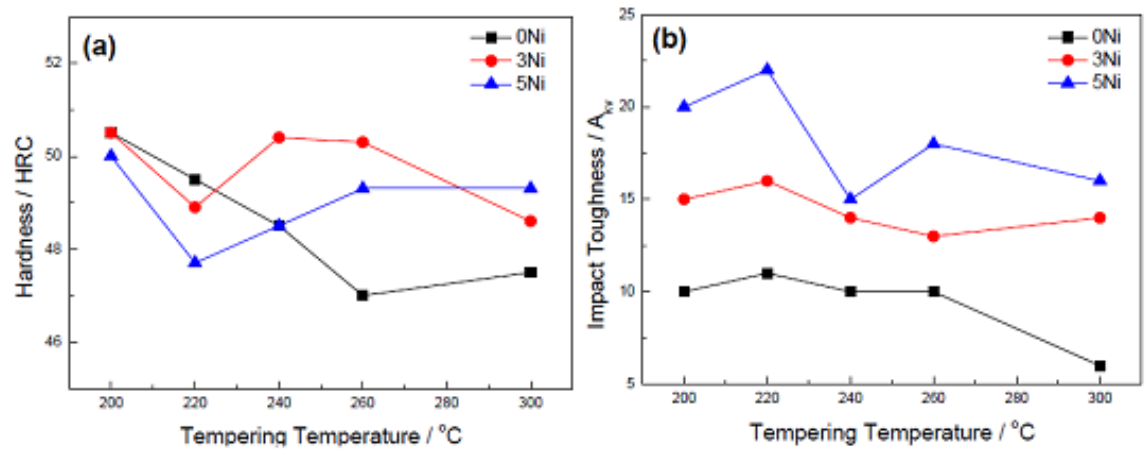

Figure 4. Effect of tempering temperature on mechanical properties of samples with different Nickel content

\subsection{Effects of vanadium on mechanical properties}

Figure 5 illustrated influences of quenching temperature on mechanical properties of vanadium steel. Figure 5(a) showed effects on hardness. As shown in the figures, when quenching at $900-940^{\circ} \mathrm{C}$, hardness of $0.22 \mathrm{wt} \% \mathrm{~V}$ steel had not changed very much. If quenching at lower $880^{\circ} \mathrm{C}$ or higher $980^{\circ} \mathrm{C}$, the hardness was about $4 \mathrm{HRC}$ lower. While for steel contains no vanadium, different tempering temperature causted a maximum hardness difference less than 2HRC. Hardness of vanadium steel was 3HRC higher than that of steel containing no vanadium. This indicated that vanadium could strengthen matrix. The tempering temperature of samples containing vanadium was higher than that of samples containing no vanadium, so that more vanadium could solve into high temperature austenite. Figure 5(b) was quenching temperature effects on impact toughness. The influence was obvious. Following increasing quenching temperature, impact toughness enhanced apparently. As it increased, for $0.22 \mathrm{wt} \% \mathrm{~V}$ steel quenching at $940^{\circ} \mathrm{C}$, ferrite on boundaries completely transited into austenite. Therefore, hardness and impact toughness of martensite formed by quenching were better than ferrite. Quenching temperature that suit $0.22 \mathrm{wt} \% \mathrm{~V}$ steel was $940^{\circ} \mathrm{C}$; For $0 \mathrm{wt} \% \mathrm{~V}$ steel, it was $960^{\circ} \mathrm{C}$.

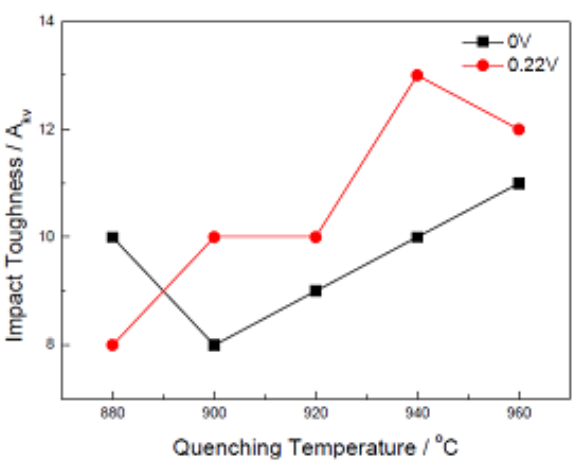

Figure 5. Mechanical properties of vanadium steel quenching at different temperature (a) effect of quenching temperature on hardness, (b) effect of quenching temperature on impact toughness

Figure 6 illustrated mechanical properties of vanadium steel with different tempering temperature. Figure 6(a) showed effects on hardness. When tempering at $220^{\circ} \mathrm{C}$, hardness of $0.22 \mathrm{wt} \% \mathrm{~V}$ steel drastically decreased, while for tempering temperature at $220-300^{\circ} \mathrm{C}$, the hardness did not change very much. This indicated that a reduced solution strengthen effect resulted by precipitation of Carbon from matrix during $220^{\circ} \mathrm{C}$ tempering. When tempering at $220-300^{\circ} \mathrm{C}$, carbide started to grow and aggregated, thus the hardness firstly increased then decreased. However, for $0 \mathrm{wt} \% \mathrm{~V}$ steel, the hardness continuously decreased with increasing tempering temperature. When tempering at $260-300^{\circ} \mathrm{C}$, hardness did not change obviously. Figure 6(b) was effects on impact toughness. As tempering temperature elevated, impact toughness of $0.22 \mathrm{wt} \% \mathrm{~V}$ steel is almost the same. It reaches its lowest value at $240^{\circ} \mathrm{C}$ tempering temperature. For $0 \mathrm{wt} \% \mathrm{~V}$ steel, when tempering at 200 $260^{\circ} \mathrm{C}$, impact toughness did not change very much. While, tempering at $300^{\circ} \mathrm{C}$, impact toughness decreased drastically. This indicated a coarsen carbide formed by $300^{\circ} \mathrm{C}$ tempering. For $0.22 \mathrm{wt} \% \mathrm{~V}$ steel, $200^{\circ} \mathrm{C}$ leads to the best property; For $0 \mathrm{wt} \% \mathrm{~V}$ steel, $220^{\circ} \mathrm{C}$. 

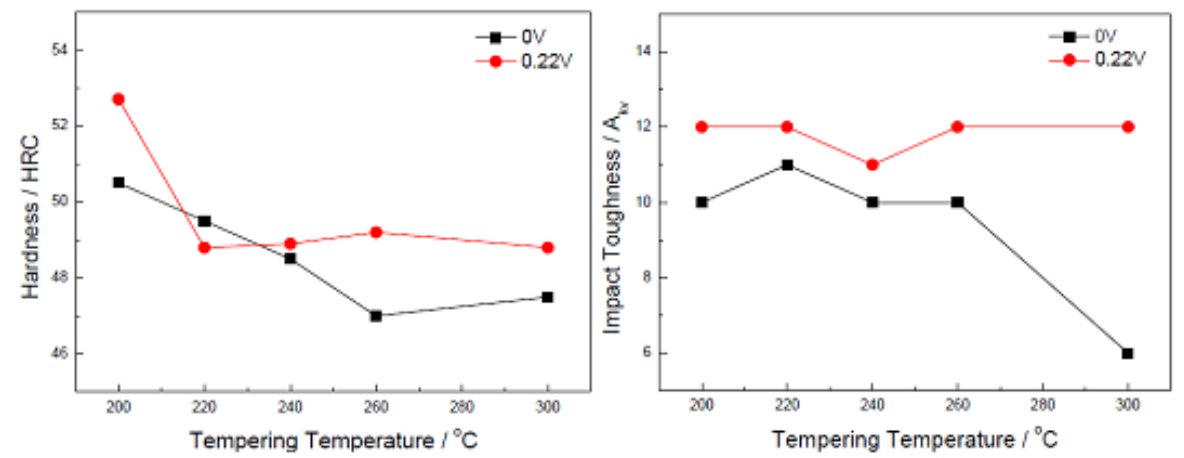

Figure 6. Mechanical properties of vanadium steel with different tempering temperature. (a) effect of tempering temperature on hardness, (b) effect of tempering temperature on impact toughness

\section{Conclusion}

Mechanical properties of low alloy wear resistant steels with different $\mathrm{C}$, $\mathrm{Ni}$ and $\mathrm{V}$ content are studied. Their changes with temperature and heat treatment time are also investigated to identify the relationship between alloy elements and properties. The conclusion were as following:

- The experimental steels yielded their best comprehensive properties at $940^{\circ} \mathrm{C}$ of quenching and at $200^{\circ} \mathrm{C}$ of tempering for $0.33 \mathrm{wt} \% \mathrm{C}$ steel, at $940^{\circ} \mathrm{C}$ of quenching and at $220^{\circ} \mathrm{C}$ of tempering for $0.38 \mathrm{wt} \% \mathrm{C}$ steel, and at $920^{\circ} \mathrm{C}$ of quenching and at $230^{\circ} \mathrm{C}$ of tempering for $0.4 \mathrm{wt} \% \mathrm{C}$ steel, respectively.

- $\quad 3 \% \mathrm{Ni}$ steel yielded the best property at $900^{\circ} \mathrm{C}$ quenching and $200^{\circ} \mathrm{C}$ tempering, while $5 \% \mathrm{Ni}$ steelwas $920^{\circ} \mathrm{C}$ quenching and $200^{\circ} \mathrm{C}$ tempering.

- $\quad$ The best property yielded at $940^{\circ} \mathrm{C}$ quenching and $200^{\circ} \mathrm{C}$ tempering for the Vanadiu addition steel.

\section{Acknowledgments}

This paper is supported by This work was financially supported by the National Science Foundation for Young Scientists of China (Grant No. 51601044, 5176504), Guangxi Natural Science Foundation (NO. 2015GXNSFBA139225, 2018JJA160266), the Opening Project of Guangxi Colleges and Universities Key Laboratory of robot \& welding: Re-search of microstructure and mechanical properties on CLAM steel after EBW and the Doctor's Research Initial Fund of Gulin University of Aerospace Technology: Researches on Rapid Die Design methods for Sheet metal, and Study on improving the microstructure stability of the heat resistant steel by modifying the precipitates.

\section{References}

1. x. DENG, Z.W. ANG, Y. HAN, et al., JOURNAL OF IRON AND STEEL RESEARCH, INTERNATIONAL, 21 (2014) 98-103.

2. B. Białobrzeska, R. Dziurka, A. Żak, et al., Archives of Civil and Mechanical Engineering, 18 (2018) 413 $-429$.
3. V. Javaheri, The international journal for computation and mathematics in electrical and electronic engineering, 39 (2020) 158-165.

4. V.G. Efremenko, V.I. Zurnadzhi, Y.G. Chabak, et al., Materials Science, 53 (2017)

5. Yuqing Weng, Caifu Yang, Chengjia Shang. Iron, 46 (2011)

6. H.Karbasian, A.E.Tekkaya, Journal of Materials Processing Technology 210 (2010) 2103-2118.

7. B. BIAŁOBRZESKA, W.D. ński, Archives of Metallurgy and Materials, 60 (2015) 1649-1656.

8. B. Białobrzeska, R. Dziurka, A. Żak, et al., Archives of Civil and Mechanical Engineering, 18 (2018) 413 -429 . 